\section{Tributun: a coffee cultivar developed in partnership with farmers}

\section{Fábio Luiz Partelli ${ }^{1 *}$, João Antonio Dutra Giles ${ }^{1}$, Gleison Oliosi ${ }^{1}$, André Monzoli Covre ${ }^{1}$, Adésio Ferreira ${ }^{2}$ and Valcir Meneguelli Rodrigues $^{3}$}

\begin{abstract}
Tributun is a cultivar of Coffea canephora derived from breeding clones discovered by farmers. It was evaluated at $150 \mathrm{~m}$ asl in northern Espírito Santo for yield, plant vigor and pest and disease resistance. The cultivar with six genotypes produces a mean yield of 90.87 bags ha $^{-1}$ year ${ }^{-1}$.
\end{abstract}

Keywords: Coffea canephora, plant resistance, climate change, conilon.

\section{INTRODUCTION}

Around 174 million bags of coffee are produced annually worldwide. Of this total output, $59.8 \%$ is coffee of the species Arabica (Coffea arabica) and $40.2 \%$ of Robusta/Conilon (C. canephora) (https://www.fas.usda.gov/data/ coffee-world-markets-and-trade). The entire coffee chain produces an annual revenue of around 173,000 million U\$D (ICO 2019), whereas Brazil accounts for approximately $32 \%$ of the global output (http://www.conab.gov.br). In view of the predicted population growth and climatic changes, more efforts should be invested in raising coffee yields and quality by sustainable and environmentally responsible actions.

Conilon coffee is a self-sterile, diploid and, in view of the gametophytic self-incompatibility, allogamous plant. In vegetatively propagated plants, the mother plant traits are maintained by inheritance, ensuring uniform crop development, higher yields, better fruit quality and the possibility of selecting varieties with different maturation cycles (Partelli et al. 2014b, Partelli et al. 2019).

Coffea canephora tolerates temperatures up to $37^{\circ} \mathrm{C}$ by the maintenance or intensification of photoprotection and antioxidant mechanisms (Martins et al. 2016, Rodrigues et al. 2016). At mean temperatures lower than 17 으 or higher than $31 \stackrel{\circ}{\circ}$, the growth of $C$. canephora trees is delayed (Partelli et al. 2010, Covre et al. 2016). In the latter case, heat can affect the plant physical characteristics, reducing grain weight and yield (Ramalho et al. 2018). A possibility of mitigating the thermal stress is to grow coffee under the shade of other trees (Partelli et al. 2014a, Oliosi et al. 2016).

Some tolerance characteristics were observed at the field scale, at low and high temperatures and under water stress, varying according to the Coffea genotypes (Covre et al. 2016, Gomes et al. 2016, Bonomo et al. 2017, Dubberstein et al. 2017, Giles et al. 2019, Partelli et al. 2019).
Crop Breeding and Applied Biotechnology 20(2): e30002025, 2020 Brazilian Society of Plant Breeding. Printed in Brazil http://dx.doi.org/10.1590/198470332020v20n2c21
*Corresponding author: E-mail: partelli@yahoo.com.br (D) ORCID: 0000-0002-8830-0846

Received: 21 November 2019 Accepted: 10 January 2020 Published: 24 March 2020

\footnotetext{
${ }^{1}$ Universidade Federal Espírito Santo, 29.932540 , São Mateus, ES, Brazil

${ }^{2}$ Universidade Federal Espírito Santo, 29.500000, Alegre, ES, Brazil

${ }^{3}$ Farmer, $29.785-000$ Vila Valério, ES, Brazil
} 


\section{FL Partelli et al.}

Regarding the suitability, Tributun is a C. canephora cultivar indicated for cultivation at low altitudes. The six genotypes were field- tested at $150 \mathrm{~m}$ asl and registered by the Brazilian Ministry of Agriculture, Livestock and Food Supply (MAPA) (http://sistemas.agricultura.gov.br/snpc/cultivarweb/cultivares_registradas.php).

\section{BREEDING PROCESS}

A group of 30 promising C. canephora genotypes (29 cutting- and one seed-propagated) was selected, propagated by cuttings and planted in an experimental plot. Selection targeted high yield potential and agronomic traits of interest, most of which had been selected by coffee farmers in the State of Espírito Santo. The experimental plot was planted in May 2012, at a spacing of $2.7 \mathrm{~m} \times 1.2 \mathrm{~m}$, totaling 3086 plants ha ${ }^{-1}$, in the county of Vila Valério, Espírito Santo, Brazil, (lat $18^{\circ} 58^{\prime} 05.00^{\prime \prime} \mathrm{S}$, long $40^{\circ} 20^{\prime} 02.00^{\prime \prime} \mathrm{W}$, alt $150 \mathrm{~m}$ asl), where the average annual temperature is $23^{\circ} \mathrm{C}$. According to Köppen, the regional climate is Aw tropical, characterized by hot humid summers and dry winters (Alvares et al. 2013), with an average annual precipitation of 1,200 $\mathrm{mm}$. The entire experimental plot was sprinkler-irrigated and the treatments arranged in a completely randomized block design with four replications, in which the different genotypes represented the treatments and each experimental unit contained four coffee plants.

In terms of management practices, weed control was performed by mechanical and chemical means and the plot was fertigated, while no micronutrients, insecticide or fungicide were applied in the study period. According to the plant requirements and phenological stages, the treatments were fertilized with $\mathrm{N}, \mathrm{P}_{2} \mathrm{O}_{5}$ and $\mathrm{K}_{2} \mathrm{O}$, respectively, at 500 , 100 and $400 \mathrm{~kg} \mathrm{ha}^{-1}$ year $^{-1}$.

The experimental plot was harvested four times in the study period (2014, 2015, 2016 and 2017), according to the maturation cycle of each genotype. Coffee yield was measured in liters per plot and later converted into bags of processed coffee per hectare, where $320 \mathrm{~L}$ equals one $60 \mathrm{~kg}$ bag of processed coffee (Barbosa et al. 2014, Oliosi et al. 2016) and, based on the plant spacing, yield per hectare was calculated.

\section{PERFORMANCE}

Yield data of the four harvests $(2014,2015,2016$ and 2017) were used for the competition assay and selection of the plant material (Table 1). Among all tested genotypes, six superior genotypes (A1, Bambural, Beira Rio 8, Clementino, Pirata and Verdim R) were selected, based on traits such as yield and apparent plant vigor, to develop a new clonal cultivar, named Tributun. The mean yield of the six genotypes across the four harvests was 90.87 bags ha $^{-1}$ year $^{-1}$ (Table 1). This mean yield might seem modest, but may have been reduced by the severe drought of 2015 and 2016 (Table 1). In addition, although apparently moderate, the yield of cv Tributun was far higher than the average Conilon coffee yield in Brazil (http://www.conab.gov.br).

With regard to the plant traits, evaluated after 477 days, the genotypes had a plant height of 76.94 to $88.56 \mathrm{~cm}$, crown diameter of 108.56 to $147.88 \mathrm{~cm}$, internode length of 2.95 to $3.99 \mathrm{~cm}$, fruit weight of 0.834 to $1.413 \mathrm{~g}$ and fruit volume of 0.852 to $1.350 \mathrm{~mL}$ (Table 1).

Table 1. Plant height and diameter 477 days after planting, plagiotropic branch node length, mature fruit weight and volume, mean yield of four harvests $(2014,2015,2016$ and 2017) and maturation

\begin{tabular}{|c|c|c|c|c|c|c|c|}
\hline Ganntunes & Height & Diameter & Internode & Weight & Volume & Yield & Maturation \\
\hline venotypes & $(\mathrm{cm})$ & $(\mathrm{cm})$ & $(\mathrm{cm})$ & (g) & $(\mathrm{mL})$ & (bags ha-1) & - \\
\hline $\mathrm{A} 1$ & 76.94 & 115.81 & 3.66 & 1.091 & 1.060 & 87.03 & Medium \\
\hline Bambural & 86.00 & 110.75 & 2.95 & 0.928 & 0.900 & 88.56 & Medium/late \\
\hline Beira Rio 8 & 84.75 & 110.50 & 3.54 & 1.413 & 1.350 & 82.72 & Early/medium \\
\hline Clementino & 88.56 & 126.00 & 3.48 & 1.046 & 0.990 & 82.52 & Medium \\
\hline Pirata & 87.50 & 147.88 & 3.91 & 1.073 & 0.977 & 105.78 & Early \\
\hline Verdim $\mathrm{R}^{1}$ & 82.38 & 108.56 & 3.10 & 0.834 & 0.852 & 98.60 & Early/medium \\
\hline Mean & $84.36 \mathrm{a}$ & $119.92 \mathrm{a}$ & $3.44 \mathrm{a}$ & $1.06 \mathrm{a}$ & $1.02 \mathrm{a}$ & $90.87 \mathrm{a}$ & \\
\hline Mean (Emcapa $\left.{ }^{2}\right)$ & $67.85 \mathrm{~b}$ & $95.00 \mathrm{~b}$ & $2.78 b$ & $0.932 \mathrm{a}$ & $0.935 a$ & $78.66 \mathrm{~b}$ & Medium/late \\
\hline
\end{tabular}


Tributun: a coffee cultivar developed in partnership with farmers

Table 2. Means of 10 leaf morpho-anatomical traits of six genotypes of cultivar Tributun

\begin{tabular}{|c|c|c|c|c|c|c|c|c|c|c|}
\hline Genotype & SN & SI & SD & SAI & PD & ED & FUN & LA & DW & SDW \\
\hline $\mathrm{A} 1$ & $17.00 \mathrm{c}$ & $20.67 c$ & $155.78 b$ & $400.58 a$ & $23.50 a$ & $17.03 a$ & $1.39 b$ & $63.81 a$ & $774.53 a$ & $12.22 \mathrm{a}$ \\
\hline Bambural & $24.38 b$ & $22.25 b$ & $223.36 a$ & $337.50 \mathrm{~b}$ & $21.14 b$ & $15.89 a$ & $1.34 b$ & $56.09 a$ & 708.49a & $13.08 a$ \\
\hline Beira Rio 8 & $25.63 a$ & $23.31 b$ & $234.82 a$ & $350.08 a$ & $21.46 a$ & $16.14 a$ & $1.30 \mathrm{~b}$ & $52.14 b$ & $665.47 a$ & $13.04 a$ \\
\hline Clementino & $28.25 a$ & $25.87 a$ & $258.87 a$ & $394.62 a$ & $23.69 a$ & $16.63 a$ & $1.44 a$ & $58.52 a$ & $880.69 a$ & $15.48 a$ \\
\hline Pirata & $19.75 c$ & $23.23 b$ & $180.98 b$ & $367.80 a$ & $22.39 a$ & $16.76 a$ & $1.38 b$ & $59.29 a$ & $628.69 a$ & $10.72 b$ \\
\hline Verdim R & $17.00 c$ & $20.27 c$ & $155.78 b$ & $374.83 a$ & $22.72 a$ & $16.40 \mathrm{a}$ & $1.40 \mathrm{~b}$ & $50.91 b$ & $619.56 a$ & $12.30 a$ \\
\hline
\end{tabular}

SN: Stomatal number; SI: Stomatal index (\%); SD: Stomatal density (number of stomata. $\mathrm{mm}^{-2}$ ); SAI: Stomatal area index ( $\left.\mu \mathrm{m}^{2}\right)$; PD: Stomatal polar diameter ( $\left.\mu \mathrm{m}\right)$; ED: Stomatal equatorial diameter $(\mu \mathrm{m})$; FUN: Stomatal functionality; LA: Leaf area $\left(\mathrm{cm}^{2}\right)$; DW: Dry weight $(\mathrm{mg})$; SDW: Specific dry weight $\left(\mathrm{mg} \mathrm{cm}^{-2}\right)$. Means followed by equal letters, in a column, do not differ by the Scott-Knott test, at 5\% probability. Data according to Giles et al. (2019).

The evaluation of the six genotypes (Table 2) showed a great variation in some leaf traits, i.e., stomatal number and density. For other traits, i.e., stomatal index, stomatal polar diameter, stomatal equatorial diameter and stomatal functionality, the variation among the six genotypes was low.

The coffee growth and yield performance of the selected genotypes in the evaluated years indicated satisfactory adaptation to the cultivation conditions at $150 \mathrm{~m}$ asl. No severe attacks of the main pests or diseases and no flowering/ pollination problems were observed. The plant vigor and leafiness were continuously good throughout the cycle. Under the soil-climatic conditions where the cultivar was developed, the maturation of the six genotypes varied from early (Pirata) to early/intermediate (Beira Rio 8 and Verdim R) and intermediate (Bambural, Clementino and A1) maturation (Table 1).

Cultivar Tributun is recommended for cultivation in areas lower than $500 \mathrm{~m}$ asl in Espírito Santo, southern Bahia and eastern Minas Gerais. Other studies, involving physiological, anatomical and biochemical analyses of the genotypes, are currently in progress.

Most of the promising genotypes were "discovered" by farmers. Thus, the initial information of each genotype is recorded as follows:

A1: Genotype initially propagated by Ivan Milanez and Hélio Dadalto, also known as $\mathrm{H}$ and H1.

Bambural: Genotype discovered and propagated by José Bonomo in the late 1980s. Superior plant found in the county of São Mateus, on a farm owned by Eliseu Bonomo.

Beira Rio 8: Initially, several plants found on a field near the Rio São José in the county of Rio Bananal, were selected and multiplied by the coffee farmers José Francisco Partelli and Valcir Meneguelli Rodrigues. After some harvests on a commercial field in Vila Valério, Valcir M. Rodrigues pre-selected six clones that were tested in a competition trial, and the clone named Beira Rio 8 was selected.

Clementino: For three years, the coffee farmer Valcir Meneguelli Rodrigues observed a coffee tree with superior performance near the roadside in the county of Vila Valério. The plant belonged to another coffee farmer, Clementino Figueira de Barros.

Pirata (also known as 24): Plant discovered by Paulo Renato Pimenta Maia, on his farm in Córrego da Areia, São Mateus, in the late 1990s. It was multiplied and propagated by Fausto Afonso Cremasco.

Verdim R: Clone of uncertain origin. Its superior performance was observed when grown on the farm of José Valiatti, in the county of Jaguaré, and was initially multiplied by Jailson Antonio do Nacimento.

\section{CLONE MAINTENANCE AND DISTRIBUTION}

Cultivar Tributun was registered as no. 37808 by the National Registry of Cultivars (Registro Nacional de Cultivares, RNC) by the Brazilian Ministry of Agriculture, Livestock and Food Supply (Ministério da Agricultura, Pecuária e Abastecimento). The Federal University of Espírito Santo (UFES) is responsible for the maintenance of the six genotypes that constitute cv Tributun. 


\section{ACKNOWLEDGMENTS}

The authors wish to thank the first breeders, i.e., the coffee farmers, who initiated the selection of most of the superior genotypes available nowadays. Thus, the names of the clones were maintained as they are known among coffee growers. We are also indebted to the Federal University of Espírito Santo (UFES) for supporting this study; the Foundation for Research and Innovation Support of Espírito Santo (FAPES) and the National Council of Scientific and Technological Development (CNPq) for the financial support.

\section{REFERENCES}

Alvares CA, Stape JL, Sentelhas PC, Gonçalves JLM and Sparovek G (2013) Köppen's climate classification map for Brazil. Meteorologische Zeitschrift 22: 711-728.

Barbosa D, Rodrigues W, Vieira H, Partelli F and Viana A (2014) Adaptability and stability of Conilon coffee in areas of high altitude. Genetics and Molecular Research 13: 7879-7888.

Bonomo DZ, Bonomo R, Partelli FL and Souza JM (2017) Performance of Conilon coffee genotypes under different adjusted crop coefficients. IRRIGA 22: 236-248.

Covre AM, Partelli FL, Bonomo R, Braun H and Ronchi CP (2016) Vegetative growth of Conilon coffee plants under two water conditions in the Atlantic region of Bahia State, Brazil. Acta Scientiarum. Agronomy 38: 535-545.

Dubberstein D, Partelli FL, Machado Dias JR and Espindula MC (2017) Influence of fertilization on coffee trees vegetative growth in west south Amazon. Coffee Science 12: 50-59.

Giles JAD, Ferreira AD, Partelli FL, Aoyama EM, Ramalho JC, Ferreira A and Falqueto AR (2019) Divergence and genetic parameters between Coffea sp. genotypes based in foliar morpho-anatomical traits. Scientia Horticulturae 245: 231-236.

Gomes WR, Rodrigues WP, Vieira HD, Oliveira MG, Dias JRM and Partelli FL (2016) Genetic diversity of standard leaf nutrients in Coffea canephora genotypes during phenological phases. Genetics and Molecular Research: 15: gmr.15048839.

ICO - International Coffee Organization (2019) Global coffee trade. Available at <http://www.ico.org/trade_statistics.asp >. Accessed on July 18, 2019.

Martins MQ, Rodrigues WP, Fortunato AS, Leitão AE, Rodrigues AP, Pais IP, Martins LD, Silva MJ, Reboredo FH, Partelli FL, Campostrini E, Tomaz MA, Scotti-Campos P, Ribeiro-Barros Al, Lidon FJC, Damatta FM and Ramalho JC (2016) Protective response mechanisms to heat stress in interaction with high [CO2] conditions in Coffea spp. Frontiers in Plant Science 7: 947.

Oliosi G, Giles JAD, Rodrigues WP, Ramalho JC and Partelli FL (2016) Microclimate and development of Coffea canephora cv. Conilon under different shading levels promoted by Australian cedar (Toona ciliata M. Roem. var. Australis). Australian Journal of Crop Science 10: 528-538.

Partelli FL, Araújo AV, Vieira HD, Dias JRM, Menezes LFT de, Ramalho JC, Partelli FL, Araújo AV, Vieira HD, Dias JRM, Menezes LFT de and Ramalho JC (2014a) Microclimate and development of "Conilon" coffee intercropped with rubber trees. Pesquisa Agropecuária Brasileira 49: 872-881.

Partelli FL, Covre AM, Oliveira MG, Alexandre RS, da Vitória EL and da Silva MB (2014b) Root system distribution and yield of "Conilon" coffee propagated by seeds or cuttings. Pesquisa Agropecuaria Brasileira 49: 349-355.

Partelli FL, Golynski A, Ferreira A, Martins MQ, Mauri AL, Ramalho JC and Vieira HD (2019) Andina - first clonal cultivar of high-altitude conilon coffee. Crop Breeding and Applied Biotechnology 19: 476-480.

Partelli FL, Vieira HD, Silva MG and Ramalho JC (2010) Seasonal vegetative growth of different age branches of conilon coffee tree. Semina:Ciencias Agrarias 31: 619-626.

Ramalho JC, Rodrigues AP, Lidon FC, Marques LMC, Leitão AE, Fortunato AS, Pais IP, Silva MJ, Scotti-Campos P, Lopes A, Reboredo FH and Ribeiro-Barros Al (2018) Stress cross-response of the antioxidative system promoted by superimposed drought and cold conditions in Coffea spp. PLoS ONE 13: e0198694.

Rodrigues WP, Martins MQ, Fortunato AS, Rodrigues AP, Semedo JN, Simões-Costa MC, Pais IP, Leitão AE, Colwell F, Goulao L, Máguas C, Maia R, Partelli FL, Campostrini E, Scotti-Campos P, Ribeiro-Barros Al, Lidon FC, DaMatta FM and Ramalho JC (2016) Long-term elevated air [CO2] strengthens photosynthetic functioning and mitigates the impact of supra-optimal temperatures in tropical Coffea arabica and C. canephora species. Global Change Biology 22: 415-31. 